\title{
FROM PERMANENCE TO QUALITY OF LIFE: SEXUAL ORIENTATION AND IDENTITY OF GENDER OF STUDENTS IN A HIGHER EDUCATION INSTITUTION IN THE BRAZILIAN NORTHEAST
}

\author{
DA PERMANÊNCIA À QUALIDADE DE VIDA: ORIENTAÇÃO SEXUAL E \\ IDENTIDADE DE GENNERO DE DISCENTES EM UMA INSTITUIÇÃO DE ENSINO \\ SUPERIOR NO NORDESTE
}

\author{
Sara Gabriela Jones dos SANTOS ${ }^{1}$; Rodrigo DORNELAS ${ }^{2}$; Kelly da SILVA ${ }^{1}$; \\ Ricardo Barbosa LIMA ${ }^{1}$; Simone Yuriko KAMEO ${ }^{1}$ \\ 1. Universidade Federal de Sergipe, Campus Prof. Antônio Garcia Filho, Lagarto, SE, Brasil. kelly.fonoufs@gmail.com; \\ 2. Universidade Federal do Rio de Janeiro, Rio de Janeiro, RJ, Brasil.
}

\begin{abstract}
To get to know the quality of life of LGBT students of a Federal University in the Northeast of the country. An analytical, comparative, exploratory, cross - sectional, quantitative, non probabilistic study with a population composed of undergraduate students from a Health Sciences Campus of the Federal University oh the Northeast Brazilian. Students in the nursing; pharmacy; physiotherapy; speech; language and hearing sciences; medicine; nutrition; dentistry and occupational therapy courses were part of the research. Among the inclusion criteria were: LGBT people, over 18 years of age, students with regular enrollment and who accepted to participate in the study by signing the Free and Informed Consent Term. Participants provided sociodemographic and quality of life information through the WHOQOL-BREF instrument. The WHOQOL-BREF examines four domains related to quality of life (physical, psychological, personal relationships and the environment. The responses followed the Likert scale (from 1 to 5 , and the higher the score, the better the quality of life). 65 students with a mean age of 21.7 years old $( \pm 3.4)$ participated in the study, of which, $22(33.8 \%)$ were female and $43(66.2 \%)$ were male. The means of responses and standard deviation in the physical, psychological, social and environmental domains were, respectively, 2.6 $\pm 0.6 ; 2.8 \pm 0.7 ; 2.7 \pm 0.7 ; 2.8 \pm 0.6$. This study aims to provide support for public policies aimed at the LGBT population, reaching the various spheres of our society, ensuring not only access, but also the permanence of this population group in different spaces, especially in the University, in a dignified, safe and healthy way.
\end{abstract}

KEYWORDS: Quality of life. LGBT population. Higher Education.

\section{INTRODUCTION}

When it comes to the quality of life of the LGBT population (Lesbian, gay, bisexual and transgender), in an extended perspective, it is necessary to consider the vulnerability and risk situations that this group is exposed on a daily basis and that is directly related to their health inequities. Factors such as stigma, discrimination and social exclusion make sexual orientation and gender identity closely related to the health of individuals, requiring specific attention to understanding and performing public policies and health services (BRASIL, 2008).

The mentioned context points to factors that can be conceived as chronic minority stressors, that exclusively affect a small group and justify the health disparities in which the individual is inserted. Regarding the LGBT population, adding the chronic universal stressors to the minority ones, there is a tendency of this group to present worse health indicators when compared to heterosexual groups. Thus, sexual orientation and health have close and important relationships to be investigated (RUSSELL; FISH, 2016).

When an individual does not conform to the concepts determined by heteronormative societies, they automatically become exposed to various types of violence (physical, verbal, psychological and sexual), leading to a tendency towards the development of psychopathologies. Anxiety, depression and suicidal behavior are not uncommon in LGBT people. There may also be the internalization of this violence, contributing to the non-adoption of healthy living habits and self-care practices (NATARELLI et al., 2015).

Even though discreetly, homophobia also persists in higher education institutions. Their manifestations gradually lose their violent character within the academic environment and become subtle actions (OSORIO; ROUSELL, 2015). The positions and perceptions of educators about sexual and 
From permanence to quality...

gender diversity are directly related to the manifestations of prejudice in educational institutions, and these professionals may present deficient education regarding the LGBT theme (SOUZA; SILVA; SANTOS, 2017).

It is necessary to face, through public policies, the implications generated by prejudice and social heteronormativity, aiming to protect the LGBT population (MELLO et al., 2011). The present study justifies the need to know the reality of sexual and gender minorities, discussing aspects relevant to the health of individuals, such as quality of life. This study aimed to know the quality of life of LGBT students of a Federal University in the Northeast of the country.

\section{MATERIAL AND METHODS}

The study was approved by the Research Ethics Committee of a Federal University, according to the CAAE opinion 83326718.9.0000.5546 and followed the ethical precepts of the Resolution 466/12, dealing with research with humans.

This is an analytical, comparative, exploratory, cross-sectional study with a quantitative approach whose sample was nonprobabilistic with a population composed of undergraduate students from a Health Sciences Campus of a Public University. Students in the nursing, pharmacy, physiotherapy, speech, language and hearing sciences, medicine, nutrition, dentistry and occupational therapy courses were part of the research.

Among the inclusion criteria are: LGBT people, over 18 years of age, students with regular enrollment and who accepted to participate in the study by signing the Free and Informed Consent Term.

For the collection of data, forms were sent to the UFS community via the virtual platform for privacy of the interviewees, Google Forms. The form addressed information on sociodemographic characteristics, as well as quality of life through the WHOQOL-BREF tool (FLECK, 2000); WHOQOL GROUP, 2017).

The definition of LGBT people was selfdeclared and based on personal identification. In order to identify LGBT students within the sample, two topics were elaborated for the participants to choose their personal identities regarding gender and sexuality.
SILVA, K. et al.

For gender, the following question was adopted: what is your personal gender identification? The available answer choices for this question were: cisgender, transgender, fluid and ' $I$ don't know how to answer'. For sexuality, the question was adopted: what is your personal identification related to sexuality? The available answer options for this question were: heterosexual, homosexual, bisexual, fluid, other and 'I do not know how to answer'.

Transgender, fluid gender, homosexual, bisexual, fluid sexuality, and other gender identities and sexualities not described and contemplated by the "other" answer option in both topics were considered and included as LGBT people. NonLGBT students data were disregarded.

The data were treated using an Excel worksheet (2010), the first two questions (How would you assess your quality of life? And How satisfied are you with your health?) and the four domains of Quality of Life were analyzed: physical (questions 3,4,10,15,16,17 and 18), psychological (questions 5,6,7,11,19 and 26), personal relations (questions 20, 21 and 22) and environment (questions 8.9,12,13,14,23,24 and 25). The responses followed the Likert scale (from 1 to 5, and the higher the score, the better the quality of life). Questions 3,4 and 26 were re-analyzed as follows (1 $=5)(2=4)(3=3)(4=2)(5=1)$, as instructed by the authors who validated the instrument.

\section{RESULTS}

A total of 65 students with a mean age of 21.7 years old $( \pm 3.4)$ participated in the study. Table 1 gives information about the gender, mean age, course, marital status, people with whom resides, and gender identity of the people participating in the research.

Regarding the first question on the questionnaire (How would you rate your quality of life?), the mean score was $2.3( \pm 0.7)$. The average answer to question 2 (How satisfied are you with your health?) was $2.6 \pm 0.9$. Table 2 shows the absolute and relative frequency of the responses obtained in each group.

The analysis of the quality of life among the interviewees, evaluating the general, physical, psychological, social relations and environmental domains is presented in Table 3 . 
Table 1. Characterization of the people participating in the research.

\begin{tabular}{|c|c|c|}
\hline Features & $\begin{array}{ll}\begin{array}{l}\text { Absolute } \\
\text { frequency) }\end{array} & \text { frequency } \\
\end{array}$ & (Relative \\
\hline \multicolumn{3}{|l|}{ Gender } \\
\hline Female & $22(33,8 \%)$ & \\
\hline Male & $43(66,2 \%)$ & \\
\hline Mean Age & $21,7 \pm 3,4$ & \\
\hline \multicolumn{3}{|l|}{ Course } \\
\hline Nursing & $14(21,5 \%)$ & \\
\hline Pharmacy & $5(7,7 \%)$ & \\
\hline Physiotherapy & $7(10,8 \%)$ & \\
\hline Speech, Language and Hearing Sciences & $5(7,7 \%)$ & \\
\hline Medicine & $19(29,2 \%)$ & \\
\hline Nutrition & $3(4,6 \%)$ & \\
\hline Dentistry & $8(12,3 \%)$ & \\
\hline Occupational Therapy & $4(6,2 \%)$ & \\
\hline \multicolumn{3}{|l|}{ Marital Status } \\
\hline Married/ Common Law Marriage & $1(1,5 \%)$ & \\
\hline Divorced & $0(0 \%)$ & \\
\hline Single & $64(98,5 \%)$ & \\
\hline \multicolumn{3}{|l|}{ People with whom resides } \\
\hline Friends/Colleagues & $23(35,4 \%)$ & \\
\hline Companions & $0(0 \%)$ & \\
\hline Parents/Parents in law & $27(41,5 \%)$ & \\
\hline Alone & $10(15,4 \%)$ & \\
\hline Other & $5(7,7 \%)$ & \\
\hline \multicolumn{3}{|l|}{ Gender Identity } \\
\hline Cisgender & $57(87,7 \%)$ & \\
\hline Transgender & $0(0 \%)$ & \\
\hline Fluid & $3(4,6 \%)$ & \\
\hline Did not know how to answer & $4(6,1 \%)$ & \\
\hline Did not declared & $1(1,5 \%)$ & \\
\hline
\end{tabular}

Table 2. Relative and absolute frequency of the initial questions of the WHOQOL Brief questionnaire. Question 1 - How would you rate your quality of life?

\begin{tabular}{cclll}
\hline 1 & 2 & 3 & 4 & 5 \\
$5(7,7 \%)$ & $37(56,9 \%)$ & $20(30,8 \%)$ & $3(4,6 \%)$ & $0(0 \%)$ \\
\hline Question 2- How satisfied are you with your health? & & & \\
\hline 1 & 2 & 3 & 4 & 5 \\
$6(9,2 \%)$ & $46(70,8 \%)$ & $19(29,2 \%)$ & $10(15,4 \%)$ & $1(1,5 \%)$ \\
\hline
\end{tabular}

The answers followed the Likert scale (from 1 to 5 , the higher the score, the better the quality of life).

Table 3. Averages obtained in the physical, psychological, social and environmental domains of the WHOQOL Brief questionnaire.

\begin{tabular}{lrrrcc}
\hline & & Physical & Psychological & Personal Relations & Environment \\
\hline $\begin{array}{l}\text { Mean } \pm \\
\text { Deviation }\end{array}$ & Standard & $2,6 \pm 0,6$ & $2,8 \pm 0,7$ & $2,7 \pm 0,7$ & $2,8 \pm 0,6$ \\
\hline
\end{tabular}




\section{DISCUSSION}

In this work, most participants identified themselves as men, cisgender, homosexual and single. Although there is a higher prevalence of women attending higher education (SANTOS; BITTENCOURT, 2017), the studies consulted were conducted without questioning sexual orientation and gender identity.

It is worth discussing the difficulty of access and permanence of transgender people in the university. Silva, Bezerra and Queiroz (2015) brings an important discussion about "The school as a locus of prejudice and discrimination reproduction". This paper discusses the difficulty of scholar access for the trans population and the reproduction of prejudice in this social environment.

In recent years there has been a growing discussion regarding the quality of life of university students (LANTYER et al., 2016; OLIVEIRA et al., 2015; CHAZAN; CAMPOS; PORTUGAL, 2015; MOURA et al., 2016). This discussion is of utmost importance as several stressors are often identified at this stage of life. However, there is a scarcity of papers discussing the quality of life of LGBT university students, and student profiles are traced only to sex, not taking into account the particularities of LGBT people.

Regarding the first question about selfperception of quality of life, it was observed that most participants rated theirs as very poor or poor. Also, in the second question that assesses satisfaction with their health, $80 \%$ of participants rated their own health between 1 and 2 on the Likert scale (Very bad and bad). These results disagree with the findings of national university surveys in which most people report their quality of life between very good and good (CATUNDA; RUIZ, 2008; MOURA et al., 2016).

This difference between national findings points to the importance of looking at gender and sexual orientation diversity within the university.

About $18 \%$ of gay and lesbian youth meet the criteria for deep depression, against $8.2 \%$ of the national rate, $11.3 \%$ for posttraumatic stress, a national rate of $3.9 \%$, and $31 \%$ have reported suicidal behavior at some point in life, while the national rate reports 4.1\% (RUSSEL; FISH, 2016).

Family rejection is directly related to health damage, as Rothman et al. (2012) shows that gay and bisexual men who received a negative response from parents about their sexuality are more likely to abuse alcohol and six times more likely to symptoms of depression, compared with those who had positive reactions from parents (WHITE et al., 2016).

The quality of life of students, especially in higher education, has been widely researched and discussed in the scientific literature. Regardless of gender identity and sexual orientation, the academic experiences and activities developed during higher education reflect directly on the health of individuals and can be considered a factor that aggravates or improves their quality of life (OLIVEIRA et al., 2015).

Still, national studies that investigate the quality of life in college students do not relate the results with different sexual orientations and gender identity. This study brings attention to the need for a look at the LGBT university population.

From this perspective, a study conducted with 208 undergraduate students of health science courses through WHOQOL-BREF identified that the best quality of life indices were present in students with lower stress levels. In this approach, there was also no analysis from the perspective of gender and sexual orientation (BORINE, 2015).

College students are in the age group in which stress-related disorders are most common. The prevalence of sleep disorders is high, in addition to depression and anxiety. Health courses can be even more strenuous due to the demanding nature of the other's health care (RIBEIRO et al., 2017).

In the present study, the general averages in the physical, psychological, personal relations and environment domains were lower than 3 , showing a compromised quality of life. Some international studies report that heterosexual populations tend to have better quality of life than LGBT populations when evaluated in various dimensions. Moreover, few studies have investigated thoroughly the relationship between different sexual orientations and gender identity with health-related quality of life (CHARLTON et al., 2018).

A study of 339 college students in four countries of the five continents (Cuba, Norway, India, and South Africa) found that LGBT academics had a low quality of life scores and lower averages when compared to non-LGBT people. Similarly, another study conducted in Nigeria investigated the relationship between sexual orientation and quality of life in 481 students. Through the WHOQOL-BREF tool, the authors identified that gays, lesbians, and bisexuals had lower means in the four domains evaluated by the instrument (TRAEEN et al., 2009; BOLADALE et al., 2015). 
A weakness of the present study was the lack of research on stressful events among participants. This study would provide a broader view, since other studies with this focus have been developed in several universities, providing a better elucidation of factors adjacent to quality of life outcomes.

The results of this study alert to the need for attention to the quality of life of LGBT university students with proposals that act to improve these findings that may impact the physical and mental health, and compromise the academic performance of these students. Measures to combat LGBTphobia should be institutionalized, therefore the university does not reproduce prejudice and ensure access and permanence of these people.

\section{CONCLUSIONS}

The general average quality was between poor and regular, highlighting the need for measures, within the university ecosystem, to help reverse this situation.

This study aims to provide support for public policies aimed at the LGBT population to reach the various spheres of our society, guaranteeing not only access, but also the permanence of this population group in different spaces, especially in the University, in a safe, healthy and dignified way.

RESUMO: Conhecer a qualidade de vida de estudantes LGBTs de uma Universidade Federal do Nordeste do País. Estudo analítico, comparativo, exploratório, transversal, com abordagem quantitativa, de amostra não probabilística com uma população composta por discentes de graduação de um Campus de Ciências da Saúde de uma Universidade Federal do Nordeste brasileiro. Fizeram parte da pesquisa discentes dos cursos de enfermagem, farmácia, fisioterapia, fonoaudiologia, medicina, nutrição, odontologia e terapia ocupacional. Dentre os critérios de inclusão estavam: pessoas LGBTs, com idade superior a 18 anos, discentes com matrícula regular e que aceitaram participar da pesquisa mediante assinatura do Termo de Consentimento Livre e Esclarecido. Os participantes forneceram informações sociodemográficas e de qualidade de vida por meio do instrumento WHOQOL-BREF. O WHOQOL-BREF analisa quatro domínios relacionados à qualidade de vida (físico, psicológico, relações pessoais e meio ambiente. As respostas seguiram uma escala de Likert (de 1 a 5, sendo que quanto maior a pontuação melhor a qualidade de vida). Participaram da pesquisa 65 discentes com idade média de 21,7 anos $( \pm 3,4)$, sendo $22(33,8 \%)$ pessoas do gênero feminino e $43(66,2 \%)$ do masculino. As médias de respostas e desvio padrão nos domínios físicos, psicológicos, relações sociais e meio ambiente foram, respectivamente, $2,6 \pm 0,6 ; 2,8 \pm 0,7 ; 2,7 \pm 0,7 ; 2,8 \pm 0,6$. Esse estudo visa dar subsídios para que as políticas públicas voltadas à população LGBT alcance as diversas esferas de nossa sociedade, garantindo não só o acesso, mas também a permanência desse grupo populacional nos diversos espaços, em especial, na Universidade, de modo digno, seguro e saudável.

PALAVRAS CHAVES: Qualidade de vida. População LGBT. Ensino Superior.

\section{REFERENCES}

BOLADALE, M.; OLAKUNLE, O.; OLUTAYO, A.; ADESANMI, A. Sexual orientation and quality of life among students of Obafemi Awolowo University (OAU), Nigeria. Afr Health Sci., v. 15, n. 4, p. 1065-1073, 2015. https://doi.org/10.4314/ahs.v15i4.3

BORINE, R. C. C.; WANDERLEY, K.S.; BASSITT, D.P. Relação entre a qualidade de vida e o estresse em acadêmicos da área da saúde. Estudos Interdisciplinares em Psicologia, v. 6, n. 1, p. 100-118, 2015. https://doi.org/10.5433/2236-6407.2015v6n1p100

BRASIL, Ministério da Saúde. Saúde da população de gays, lésbicas, bissexuais, travestis e transexuais. Rev. Saúde Públ. N. 42, p. 570-573, 2008. https://doi.org/10.1590/S0034-89102008000300027

CATUNDA, M. A. P.; RUIZ, V. M. Qualidade de vida de universitários. Pensamento Plural: Revista Científica do Unifae, v.2, n.1, 2008 . 
CHARLTON, B. M.; GORDON A. R.; REISNER, S. L.; SARDA, V.; SAMNALIEV, M.; AUSTIN, S. B. Sexual orientation-related disparities in employment, health insurance, healthcare access and health-related quality of life: a cohort study of US male and female adolescents and young adults. BMJ open, v. 8, n. 6, 2018. https://doi.org/10.1136/bmjopen-2017-020418

CHAZAN, A. C. S.; CAMPOS, M. R.; PORTUGAL, F. B. Qualidade de vida de estudantes de medicina da UERJ por meio do Whoqol-bref: uma abordagem multivariada. Ciênc. saúde coletiva, Rio de Janeiro, v. 20, n. 2, p. 547-556, Feb. 2015. Available from

$<$ http://www.scielo.br/scielo.php?script=sci_arttext\&pid=S1413-81232015000200547\&lng=en\&nrm=iso $>$. access on 04 Nov. 2019. http://dx.doi.org/10.1590/1413-81232015202.05182014.

FLECK, M. P. A. O instrumento de avaliação de qualidade de vida da Organização Mundial de Saúde (WHOQOL-100): características e perscpectivas. Ciênc. Saúde Colet., v.5, n.1, p.33-8,2000. https://doi.org/10.1590/S1413-81232000000100004

GRUPO WHOQOL. Whoqol Abreviado: Programa de Saúde Mental, Organização Mundial da Saúde, Genebra. Disponível em: <http://www.brasileir-osnomundo.itamaraty.gov.br/temas-sociais/questionarios-socioeconomicos/programa-de-saude-mental>. Acesso em: 07 de nov. 2017.

LANTYER, A. S.; VARANDA, C. C.; SOUZA, F. G.; PADOVANI, R. C.; VIANA, M. B. Ansiedade e Qualidade de Vida entre Estudantes Universitários Ingressantes: Avaliação e Intervenção. Rev. Bras. de Ter. Comp. Cogn. v.18, n. 2, p. 4-19, 2016. https://doi.org/10.31505/rbtcc.v18i2.880

MELLO, L.; PERILO, M.; BRAZ C. A.; PEDROSA, C. Políticas de saúde para lésbicas, gays, bissexuais, travestis e transexuais no Brasil: em busca de universalidade, integralidade e equidade. Sex., Salud Soc. (Rio J.). n.9, p.7-28, 2011. https://doi.org/10.1590/S1984-64872011000400002

MOURA, I. H. NOBRE, R. S.; CORTEZ, R. M. A.; CAMPELO, V.; MACÊDO, S. F.; SILVA, A. R. V. Qualidade de vida de estudantes de graduação em enfermagem. Rev. Gaúcha Enferm., Porto Alegre, v. 37, n. 2, p. e55291, 2016. Available from $<\mathrm{http}: / / \mathrm{www}$. scielo.br/scielo.php?script=sci_arttext\&pid=S198314472016000200407\&lng=en\&nrm=iso $>$. access on 04 Nov. 2019. Epub May 31, 2016. http://dx.doi.org/10.1590/1983-1447.2016.02.55291.

NATARELLI, T. R. P.; BRAGA, I. F.; OLIVEIRA, W. A.; SILVA, M. A. J. O impacto da homofobia na saúde do adolescente. Esc Anna Nery, Ribeirão Preto, v. 19, n. 4, p. 664-9, out-dez, 2015.

OLIVEIRA, H. F.; RISSO, H. R. F.; VIEIRA, F. S. F; LEAL, K. A. S.; NOVELLI, C.; NODA, D. K. G.; MARTINS, G. C.; CASAGRANDE, R. M.; CAMARGO, L. B; PASSOS, R. P.; VILELA JUNIOR, G. B. Estresse e qualidade de vida de estudantes universitários. CPAQV Journal, v. 7, n. 2, 2015.

OSORIO, J. M. P.; ROUSELL, H. B. A. Homofobia en estudiantes universitarios de México Juan Manuel. Región y Sociedad. v.27, n. 64, p. 5-35, 2015. https://doi.org/10.22198/rys.2015.64.a309

RIBEIRO, I. J. S.; PEREIRA, R.; FREIRE, I. V.; OLIVEIRA, B. G.; CASOTTI, C. A.; BOERY, E. N. Stress and quality of life among university students: a systematic literature review. Health Prof. Educ. v. 4, n. 2, p. 707, 2017. https://doi.org/10.1016/j.hpe.2017.03.002

ROTHMAN, E. F.; SULLIVAN, M.; KEYES, S.; BOEHMER, U. Parents' supportive reactions to sexual orientation disclosure associated with better health: results from a population-based survey of LGB adults in Massachusetts. J Homosex. v. 59, n. 2, p. 186-200, 2012. https://doi.org/10.1080/00918369.2012.648878

RUSSEL, S.; FISH, J. N. Mental Health in Lesbian, Gay, Bisexual, and Transgender (LGBT) Youth. Ann. rev. clin. psychol. v. 12, p. 465-87, 2016. https://doi.org/10.1146/annurev-clinpsy-021815-093153 
SANTOS, B. O.; BITTENCOURT, F. O. Análise da qualidade de vida e fatores associados dos acadêmicos da área de saúde de uma faculdade particular. Id on Line Rev. Psic. v.10, n. 33, 2017.

https://doi.org/10.14295/idonline.v10i33.611

SILVA R. G. L. B.; BEZERRA, W. C.; QUEIROZ, S. B. Os impactos das identidades transgênero na sociabilidade de travestis e mulheres transexuais. Rev Ter Ocup Univ São Paulo. v. 26, n. 3, p. 364-72, 2015. https://doi.org/10.11606/issn.2238-6149.v26i3p364-372

SOUZA, E. J.; SILVA, J. P.; SANTOS, C. Representações de docentes acerca da diversidade sexual e homofobia. Ver. Estud. Fem., v. 25, n. 2, p. 519-44, 2017. https://doi.org/10.1590/1806-9584.2017v25n2p519

TRAEEN, B.; TRAEEN, B.; MARTINUSSEN, M.; VITTERSØ, J.; SAINI, S. Sexual orientation and quality of life among university students from Cuba, Norway, India, and South Africa. J Homosex., v. 56, n. 5, p. 655669, 2009. https://doi.org/10.1080/00918360903005311

WHITE, Y. I, SANDFORT, T.; MORGAN, K.; CARPENTER, K.; PIERRE, R. Family relationships and sexual orientation disclosure to Family by gay and bisexual men in Jamaica. Int J Sex Health., v. 28, p. 306-17, 2016. https://doi.org/10.1080/19317611.2016.1227015 